\title{
Effect of sodium chloride, potassium chloride on germination and growth of Foxtail millet (Setaria italica L.)
}

\author{
Kiran Natasha ${ }^{1}$, Syed Inzimam Ul Haq ${ }^{2 *}$, Sheraz Ahmad ${ }^{1}$, Zakir Ullah ${ }^{3}$
} and Zubia Rahim ${ }^{4}$

1. Department of Botany, Qurtuba University of Science \& Information Technology, Peshawar, KPK-Pakistan

2. Department of Botany, Islamia College Peshawar, KPK-Pakistan

3. Department of Botany, Abdul Wali Khan University, Mardan, KPK-Pakistan

4. Department of Botany, Women University Swabi, KPK-Pakistan

*Corresponding author's email: syedinzimam74@gmail.com

Citation

Kiran Natasha, Syed Inzimam Ul Haq, Sheraz Ahmad, Zakir Ullah and Zubia Rahim. Effect of sodium chloride, potassium chloride on germination and growth of Foxtail millet (Setaria italica L.). Pure and Applied Biology. Vol. 8, Issue 2, pp1398-1407. http://dx.doi.org/10.19045/bspab.2019.80080

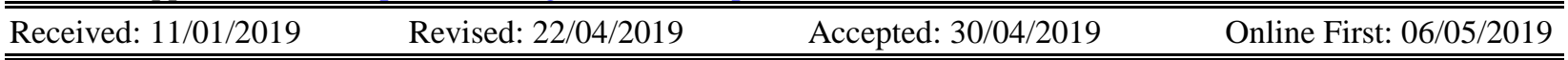

\section{Abstract}

Foxtail millet (Setaria italica L.) is the second most important species of Millet belonging to family Poaceae. It is a cereal crop mainly planted in poor sites of East Asia. In the present study the impact of different concentrations (100 mM, $150 \mathrm{mM}, 200 \mathrm{mM}$, and $250 \mathrm{mM})$ of $\mathrm{NaCl}, \mathrm{KCl}$ separate and in combination of both these salts in equal amounts was studied on germination rate and some growth parameters of foxtail millet (Setaria italica L.) using filter paper bioassay and pot experiment. Results showed that $100 \mathrm{mM}$ of $\mathrm{NaCl}$ and $\mathrm{KCl}$ had the least effect on germination and growth of foxtail millet. However, under all the higher concentrations $(150,200$, and $250 \mathrm{mM})$ of $\mathrm{NaCl}, \mathrm{KCl}$ marked decrease in radicle length, plumule length, germination rate, stem length, stem thickness, leaves length, leaves number, number of tillers, whole plant weight, spike length, number of grains per spike and weight of 50 grains was recorded as compared to control plants. In combined salts stress, a marked reduction in all growth parameters of the test plant in all salt levels was recorded. It is concluded that with an increase in salt concentration, the effects of salt stress became more pronounced in all salt treatments. The results revealed that the effects of combined salts on the test plants were more pronounced as compared to the effects when the plants were treated with $\mathrm{NaCl}$ and $\mathrm{KCl}$ salts alone.

Keywords: Foxtail millet (Setaria italic L.); KCl; NaCl; Poaceae; Salt stress

\section{Introduction}

Millets are small-seeded annual $\mathrm{C}_{4}$ grasses having a short life cycle. Millets belong to family Poaceae. It includes five genera: Setaria, Pennisetum, Panicum, Echinochloa, and Paspalum. Millets are rich in minerals, vitamins, phytochemicals, and protein and can be consumed as a good source of energy [1]. Foxtail millet (Setaria italica L.) and barnyard millet (Echinochloa frumentacea) are the cultivated species. Foxtail millet (Setaria italica L.) is the second most important species of millet. It is a cereal crop for poor people, planted mainly in East Asia including Bangladesh, India, and China. Plant growth and yield are affected by a number of biotic and abiotic factors. Abiotic factors are drought [2], cold [3], high temperature [4], salinity [5], heavy metals [6] and ultraviolet radiations [7]. Increased soil 
salinity is amongst the major factors affecting plant productivity as compared to other abiotic stresses [8, 9]. Salinity affects morphological development as well as a number of physiological processes such as gaseous exchange, protein synthesis, the activities of antioxidants, disruption of membrane functions [10-12] and oxidative stress [13]. Salinity also reduces $\mathrm{CO}_{2}$ assimilation due to which metabolic activities of microorganisms get disturbed [14]. It also decreases the water potential and ionic imbalance due to the accumulation of certain ions like $\mathrm{Na}^{+}$and $\mathrm{Cl}^{-}$and the high concentration of these ions become toxic to root cell or may cause nutritional imbalances [15-17]. More than 800 million hectares of land around the world has been recorded unproductive due to salinity [18]. The decline in production of crops has been reached to 50 percent [19]. In Pakistan, almost $12.9 \%$ of the land is adversely affected by salinity [20]. Salts of sodium, calcium, magnesium, are found in soil in large amount while those of potassium, carbonate, and bicarbonate are found in small amounts [21]. Salt stress is divided into two main types of stresses on the basis of the origin of salts from different compounds i.e. natural salt stress and alkaline salt stress [22]. The salt tolerance of the plant can be checked and improved with the exogenous application of certain stress alleviating chemicals [23]. The main purpose of this study was to examine the effect of sodium chloride, potassium chloride and combination of both salts on various parameters of foxtail millet (Setaria italica L.) including germination rate, plumule length, radicle length in filter paper bioassay and stem length and thickness, number of tillers, number and length of leaves, spike length, weight of whole plant, number of seeds per spike and weight of 50 seeds under pot experiment.

\section{Materials and methods \\ Filter paper bioassay Sterilization of petri dishes}

To avoid microbial activities petri dishes selected for lab experiments were first washed, and then sterilized for 72 hours at 100 degrees centigrade. Seeds of Foxtail millet (Setaria italica) were germinated in these sterilized petri dishes.

\section{Seeds germination and salt treatments}

Stock solutions of $100 \mathrm{mM}, 150 \mathrm{mM}$ and 200 $\mathrm{mM}$ each of $\mathrm{NaCl}$ and $\mathrm{KCl}$. For combined effect, solutions of the respective concentrations of both the salts were mixed in equal proportion. All the solution was stored at $4{ }^{\circ} \mathrm{C}$ till use. Five seeds of foxtail millet were placed on two-fold filter paper in three Petri dishes and were provided with 100 $\mathrm{mM}$ of the respective salts solution or distilled water in case of control. After 10 days, different parameters like seed germination rate, and length of radicle and plumule of the seedlings were recorded.

\section{Pot culture experiment}

Three sets with 15 pots each were prepared by filling each pot with $5 \mathrm{~kg}$ mixture of soil and sand (3:1). The pots were lined with plastic bags to prevent leaching. After that, 10 seeds of foxtail millet were sown in each pot. - The first set was used for $\mathrm{NaCl}$ treatment in which 3 pots were treated with $100 \mathrm{mM}$ salt concentrations, 3 pots with 150 $\mathrm{mM}, 3$ pots with $200 \mathrm{mM}, 3$ pots with 250 $\mathrm{mM}$ and 3 pots were run as a control. Similarly, set 2 and 3 consisted of the same number of pots and treated with the same concentrations but utilized $\mathrm{KCl}$ solutions or combined salts treatment $(\mathrm{NaCl}+\mathrm{KCl})$. Thinning of plants was done by hand picking, leaving 5 plants in each pot. A total of three salt doses of the described concentrations were applied after every seven days. The first salt stress was applied at the two-leaf stage. Data of different parameters were recorded after every 7 days. The studied parameters included stem length and thickness, number 
of leaves and tillers, leaves length, spike length, the weight of the whole plant, number of seeds per spike, the weight of 50 seeds in each concentration and control. The recorded data were then arranged into figures and tables.

\section{Results}

\section{Laboratory work}

The percent germination, plumule and radicle length of foxtail millet plants under different concentrations of $\mathrm{NaCl}, \mathrm{KCl}$, and combination of both salts were recorded after 10 days of the seedlings.

Effect of $\mathrm{NaCl}, \mathrm{KCl}$ and combined salt stress on percent germination

All the treatments of different salts $(\mathrm{NaCl}$, $\mathrm{KCl}$, and $\mathrm{NaCl}+\mathrm{KCl}$ ) reduced percent germination of foxtail millet (Figure 1). Germination was reduced to $80 \%$ and $70 \%$ by $150 \mathrm{mM}$ of $\mathrm{NaCl}$ and $\mathrm{KCl}$ solution. Treatments of $200 \mathrm{mM}$ of $\mathrm{NaCl}$ and $\mathrm{KCl}$ also reduced $60 \%$ and $50 \%$ germination respectively. The maximum reduction in percent germination was observed in 200 $\mathrm{mM}$ concentration of $\mathrm{NaCl}+\mathrm{KCl}$ solution. From the results, it is revealed that $\mathrm{NaCl}+\mathrm{KCl}$ act as a stronger inhibitor for the germination of the plant as compared to individual plants stress.

Effect of $\mathrm{NaCl}, \mathrm{KCl}$ and combined salt stress on plumule length

The influence on plumule growth increased with increasing salt levels (Figure 2). Least effect on plumule length of foxtail millet was noted in $100 \mathrm{mM} \mathrm{NaCl}$ concentration, which is $2.9 \mathrm{~cm}$ compared to $5.9 \mathrm{~cm}$ in control. Results revealed that $\mathrm{KCl}$ inhibited plumule growth of foxtail millet in all the three concentrations than $\mathrm{NaCl}$. The effect of combined salts on plumule length was more prominent as compared to the effect of individual salt. In high concentration of 200 $\mathrm{mM}$, the effect on radicle length increased many folds reducing its length to $0.9 \mathrm{~cm}, 0.4$ $\mathrm{cm}$ in $\mathrm{NaCl}$ and $\mathrm{KCl}$ respectively. The combined salts in high concentrations totally inhibited the plumule length of foxtail millet as compared to $5.9 \mathrm{~cm}$ recorded in control.

Effect of $\mathrm{NaCl}, \mathrm{KCl}$ and combined salt stress on radicle length

Foxtail millet showed a significant reduction in radicle length in all concentrations of combined salts. The maximum reduction in radicle length has been recorded in $200 \mathrm{mM}$ concentration of combined salts which is 0.2 $\mathrm{cm}$ compared to $3.7 \mathrm{~cm}$ in control. Lowest effect on radicle length is noted at $100 \mathrm{mM}$ of all the three types of salt treatments compared to control. With increasing salt concentrations their effects became more profound in all treatments. Radicle length in $100 \mathrm{mM}, 150 \mathrm{mM}$, and $200 \mathrm{mM} \mathrm{NaCl}$ concentration is $1.9 \mathrm{~cm}, 1.8 \mathrm{~cm}$, and $1.5 \mathrm{~cm}$ respectively. Similarly, radicle length in 100 $\mathrm{mM}, \quad 150 \mathrm{mM}$, and $200 \mathrm{mM}$ of $\mathrm{KCl}$ concentrations is $1.1 \mathrm{~cm}, 0.7 \mathrm{~cm}$ and $0.5 \mathrm{~cm}$ respectively (Figure 3).

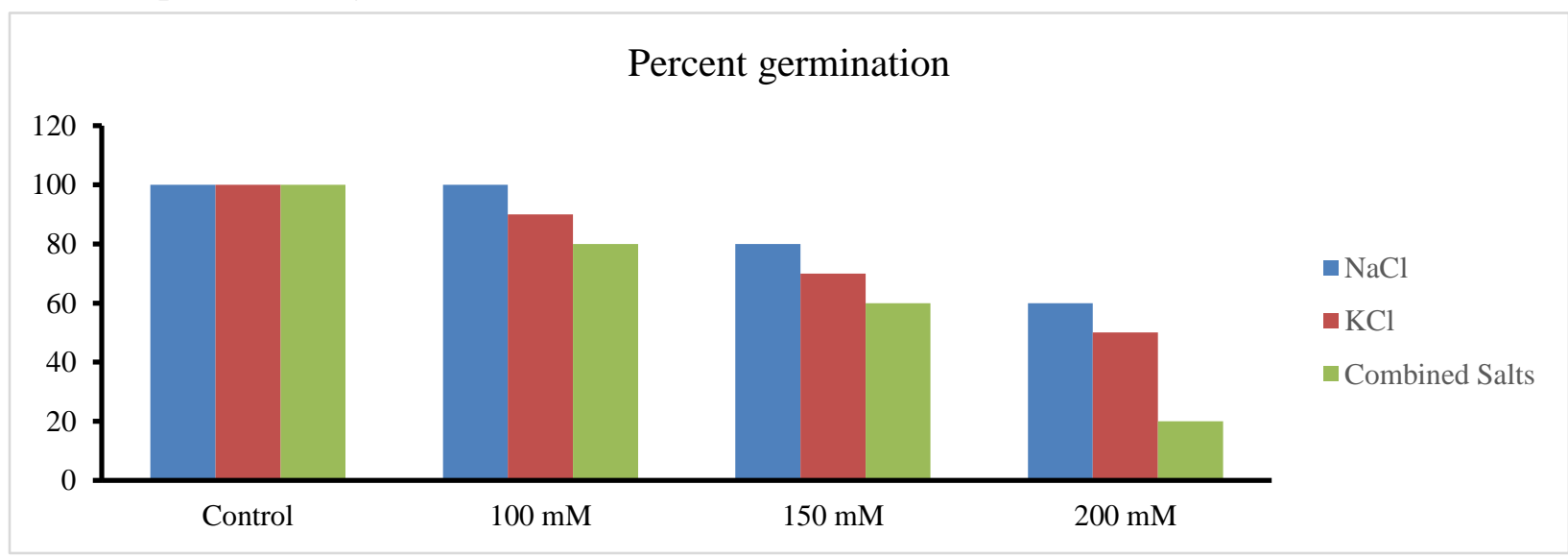


Figure 1. Effect of $\mathrm{NaCl}, \mathrm{KCl}$ and Combined salt stress on Percent germination

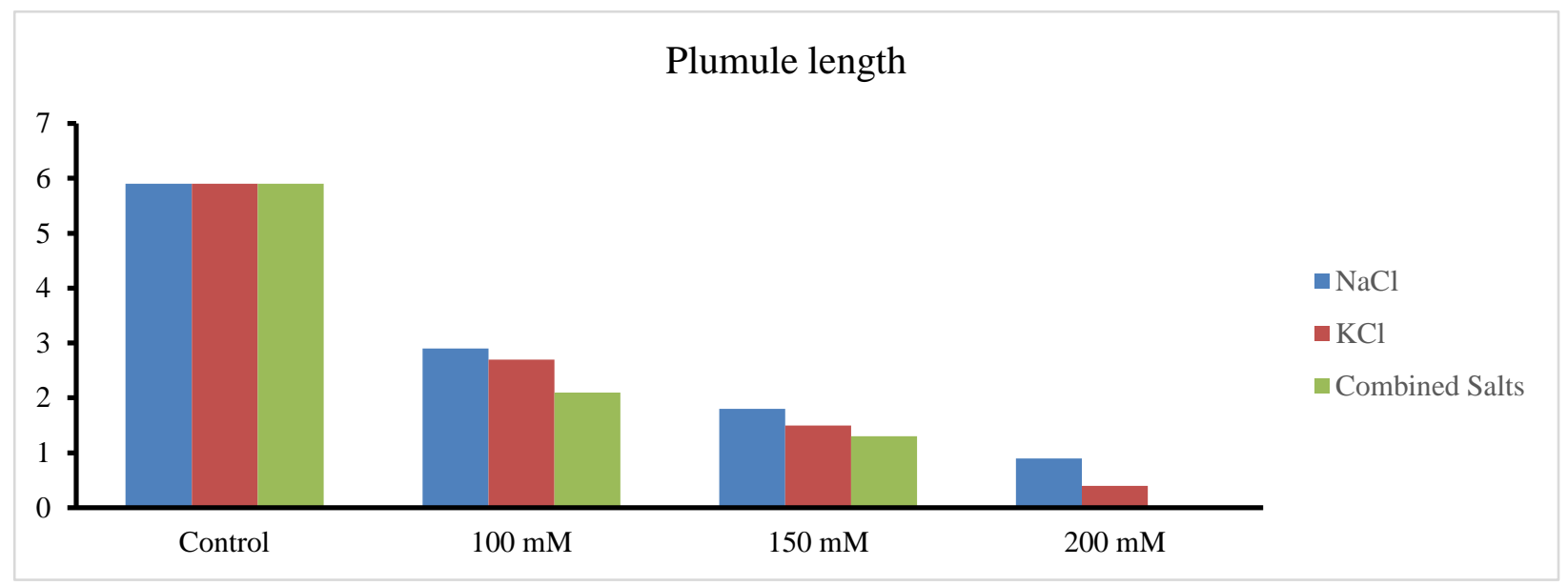

Figure 2. Effect of $\mathrm{NaCl}, \mathrm{KCl}$ and Combined salt stress on plumule length

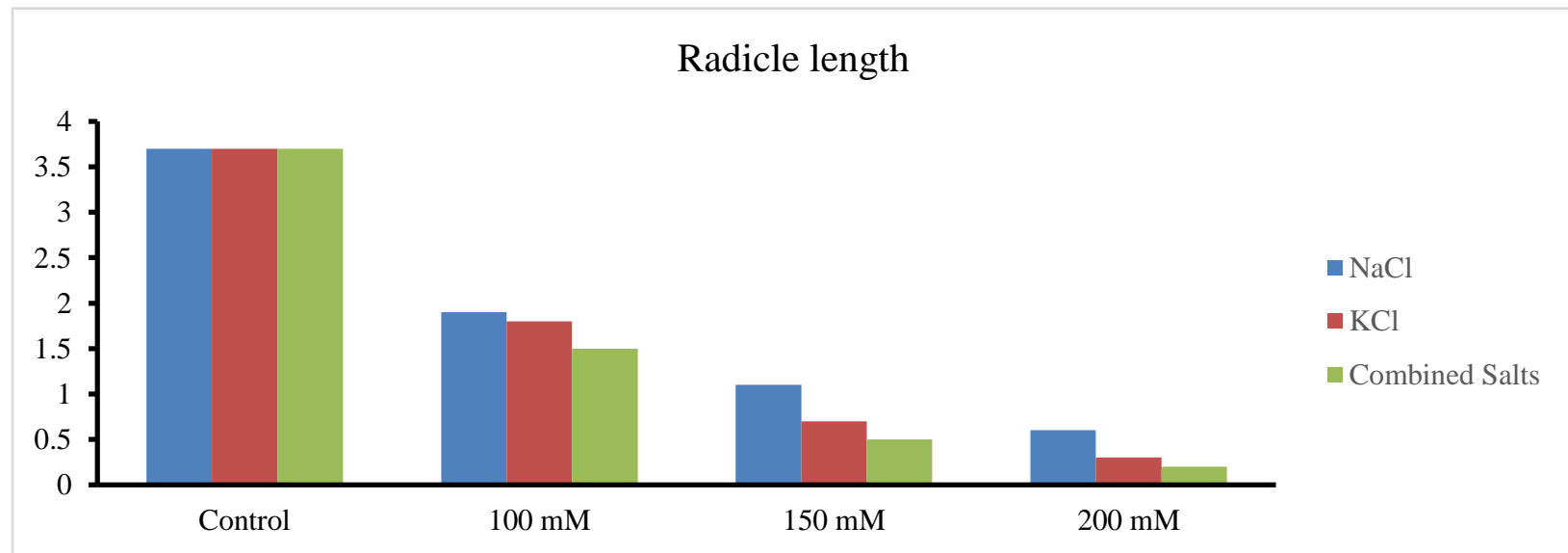

Figure 3. Effect of $\mathrm{NaCl}, \mathrm{KCl}$ and Combined salt stress on radicle length

Field Work

Effect of $\mathrm{NaCl}, \mathrm{KCl}$ and combined salts on stem length and stem breadth

Stem length

Maximum stem length was observed at control in all three doses while dramatic effects of $\mathrm{NaCl}, \mathrm{KCl}$ and combined salts on stem length were observed at higher salt concentrations. At $100 \mathrm{mM}$ concentration, a slight reduction in stem length has been observed. At $150 \mathrm{mM}$ of $\mathrm{NaCl}$, stem length was $5.8 \mathrm{~cm}, 9.7 \mathrm{~cm}$ and $52 \mathrm{~cm}$ for dose 1 , dose 2 , and dose 3 respectively. Similarly, a gradual reduction in stem length was observed at $200 \mathrm{mM} \mathrm{NaCl}$. At $250 \mathrm{mM}$ of $\mathrm{NaCl}$ stem length reduced to $4.2 \mathrm{~cm}, 7.4 \mathrm{~cm}$, and $38 \mathrm{~cm}$ in dose 1 , dose 2 , and dose 3 respectively (Table 1). Lowest effects on stem length of foxtail millet were noted in $100 \mathrm{mM} \mathrm{KCl}$ concentration i.e. $5.8 \mathrm{~cm}, 9.6$ $\mathrm{cm}, 48 \mathrm{~cm}$ in all three doses respectively. After the application of dose 3, the length of the stem was $45 \mathrm{~cm}, 40 \mathrm{~cm}$ and $36.8 \mathrm{~cm}$ in $150 \mathrm{mM}, 200 \mathrm{mM}$, and $250 \mathrm{mM}$ respectively. By comparing results of stem length in case of combined salt treatment with individual treatments, it is clear that stem length is badly 
affected in all the concentration of combined salts of $\mathrm{NaCl}$ and $\mathrm{KCl}$.

\section{Stem breadth}

In (Table 1) indicated that stem breadth recorded to be 0.2 in control which is similar to the effect of $\mathrm{NaCl}$ stress at $100 \mathrm{mM}$ concentration. In $150 \mathrm{mM}$ concentration of $\mathrm{NaCl}$ stem breadth was recorded to be $0.2 \mathrm{~cm}$, $0.2 \mathrm{~cm}$ and $0.3 \mathrm{~cm}$ for dose 1 dose 2 and dose 3 respectively. While $200 \mathrm{mM}$ and $250 \mathrm{mM}$ have the same effect at all the three doses. Maximum stem breadth was recorded at dose $3(0.4 \mathrm{~cm})$ in control plants. The minimum stem breadth was recorded $(0.2 \mathrm{~cm})$ in 250 $\mathrm{mM}$ concentration of $\mathrm{NaCl}$. In case of $\mathrm{KCl}$ (Table 1), the effect of $100 \mathrm{mM}$ concentrations on stem breadth in dose 1 and dose 2 was niggling while maximum in dose $3(0.3 \mathrm{~cm})$ as compared to control $(0.4 \mathrm{~cm})$. Maximum reduction $(0.2 \mathrm{~cm})$ in stem breadth has been observed at $200 \mathrm{mM}$ and $250 \mathrm{mM}$ in dose $3(0.2 \mathrm{~cm})$ as compared to control $(0.4$ $\mathrm{cm})$. In comparison to $\mathrm{NaCl}$, the effect of $\mathrm{KCl}$ stress on stem breadth was slightly adverse. The treatments of $150 \mathrm{mM}, 200 \mathrm{mM}$, and 250 $\mathrm{mM}$ concentrations of combined salts negatively affected stem breadth and it was minimum in $250 \mathrm{mM}(0.2 \mathrm{~cm})$ compared to control $(0.4 \mathrm{~cm})$ in dose 3 . Results showed that combined salts adversely affected stem breadth compared to $\mathrm{NaCl}$ and $\mathrm{KCl}$.

Effect of $\mathrm{NaCl}, \mathrm{KCl}$ and combined salts on leaf length and number

\section{Leaf length}

In (Table 2) revealed that in $100 \mathrm{mM}$ and 150 $\mathrm{mM}$ treatment of $\mathrm{NaCl}$, no marked reduction in leaf length was observed. In $250 \mathrm{mM}$ of $\mathrm{NaCl}$, leaf length was reduced to $6.9 \mathrm{~cm}, 7$ $\mathrm{cm}$ and $14 \mathrm{~cm}$ in dose 1, dose 2, and dose 3 respectively. An inverse relationship was observed among leaf length and increasing salt concentrations. Under high concentration of $\mathrm{KCl}$, leaf length was adversely affected as compared to control $(24 \mathrm{~cm})$ and the leaf length recorded in dose 3 was $16 \mathrm{~cm}, 15 \mathrm{~cm}$ and $13 \mathrm{~cm}$ in $150 \mathrm{mM}, 200 \mathrm{mM}$ and $250 \mathrm{mM}$ respectively. $\mathrm{KCl}$ is posing stronger stress on leaf length in comparison to $\mathrm{NaCl}$. At 150 $\mathrm{mM}$ combined salt stress, the leaf length was recorded to be $6.8 \mathrm{~cm}, 7.5 \mathrm{~cm}$ and $15 \mathrm{~cm}$ for dose 1 , dose 2 and dose 3 respectively. In 250 $\mathrm{mM}$ leaf length has been reduced to $5.8 \mathrm{~cm}$, $6.3 \mathrm{~cm}$ and $12 \mathrm{~cm}$ for dose 1 , dose 2 and dose 3 respectively. It is clear that leaf length is severely affected in all the concentration of combined salts of $\mathrm{NaCl}$ and $\mathrm{KCl}$.

\section{Number of leaves}

The higher number of leaves were counted in all doses of control plants (Table 2). The lower concentration $(100 \mathrm{mM})$ of $\mathrm{NaCl}$ had the least effect on the number of leaves. In $150 \mathrm{mM} \mathrm{NaCl}$ treatment 5, 8.4 and 11.5 mean number of leaves was counted in dose 1 , dose 2 and dose 3 respectively. The $\mathrm{KCl}$ treatment decreased the mean number of leaves more effectively as compared to $\mathrm{NaCl}$ (Table 2). The maximum number of leaves were counted in control (16) in dose 3 and a minimum number of leaves (7) were counted in $250 \mathrm{mM} \mathrm{KCl}$ solution in dose 3. In 200 $\mathrm{mM} \mathrm{KCl}$ treatment mean a number of leaves recorded to be 5, 7.5 and 9 in the three doses respectively. In $150 \mathrm{mM}$ and $200 \mathrm{mM}$, leaves mean number reduced to 7 and 6.4 after application of dose 2 as compared to 9.7 in control plants. Minimum values of leaf number i.e. 6.5 and 7 were observed in dose 2 and dose 3 respectively at $250 \mathrm{mM}$ concentration.

\section{Effect of $\mathrm{NaCl}, \mathrm{KCl}$ and combined salts on} number of tillers

In $100 \mathrm{mM}$ of $\mathrm{KCl} 0,2$ and 4 tillers were observed in dose 1 , dose 2 and dose 3 respectively, whereas the number of tillers was counted to be 0,2 and 3 at same doses in $150 \mathrm{mM}$ of $\mathrm{KCl}$. The number of tillers was approximately the same in both $100 \mathrm{mM}$ and $150 \mathrm{mM}$ concentrations of $\mathrm{KCl}$. However, in $200 \mathrm{mM}$ and $250 \mathrm{mM}$ of $\mathrm{KCl}$, only one tiller appeared in dose 2, while in $200 \mathrm{mM}$ of one more tiller appeared at dose $3 . \mathrm{KCl}$ treatment highly reduced the number of tillers as 
compared to $\mathrm{NaCl}$. The impact of combined salt on a number of tillers is more pronounced (Table 3). In $200 \mathrm{mM}$ and $250 \mathrm{mM}$ concentration of $\mathrm{NaCl}+\mathrm{KCl}$ highly reduced tiller number in dose 2 and dose 3 i.e. only one tiller was observed in both salt doses. Combination of both salts $(\mathrm{NaCl}+\mathrm{KCl})$ profoundly affected the appearance of tillers in all salt concentration as compared to $\mathrm{KCl}$ and $\mathrm{NaCl}$ stress alone.

Effect of $\mathrm{NaCl}, \mathrm{KCl}$ and combined salts on Spike length, plant weight and weight of 50 grains

\section{Spike length}

In (Table 4) showed that the spike length was maximum $(10.2 \mathrm{~cm})$ at control and minimum $(2.1 \mathrm{~cm})$ at $250 \mathrm{mM}$ of combined salts. Lowest effect on spike length of foxtail millet was noted in $100 \mathrm{mM}$ concentration of $\mathrm{NaCl}$ with the spike length of $6.1 \mathrm{~cm}$ compared to $10.2 \mathrm{~cm}$ in control. Combined salts profoundly affected the spike length in all treatment as compared to $\mathrm{NaCl}$ and $\mathrm{KCl}$ alone. In higher salt concentration of 250 $\mathrm{mM}$, the effect on spike length increased many folds reducing its length to $2.7 \mathrm{~cm}$ in $\mathrm{NaCl}$ and in $\mathrm{KCl}$ respectively. Spike length of the plant in $250 \mathrm{mM}$ of combined salts was $2.1 \mathrm{~cm}$, which is very low as compared to control plants i.e. $10.2 \mathrm{~cm}$.

\section{Plant weight}

Results (Table 4) showed that in case of $\mathrm{NaCl}$ treatment, plant weight was $3.4 \mathrm{~g}, 2.4 \mathrm{~g}, 1.6$ $\mathrm{g}$ and $1.1 \mathrm{~g}$ in $100 \mathrm{mM}, 150 \mathrm{mM}, 200 \mathrm{mM}$, and $250 \mathrm{mM}$ concentrations respectively. The effect of salt stress was more pronounced under higher salt levels of $\mathrm{NaCl}$. The maximum reduction in plant weight has been recorded at $200 \mathrm{mM}$ of combined salts $(0.6 \mathrm{~g})$ and $\mathrm{KCl}$ salt. Similar plant weight $(1.3 \mathrm{~g})$ has been recorded at $150 \mathrm{mM}$ of both $\mathrm{NaCl}$ and $\mathrm{KCl}$.

\section{The weight of 50 grains}

Weight of 50 grains was recorded to be $0.8 \mathrm{~g}$, $0.6 \mathrm{~g}, 0.4 \mathrm{~g}$ and $0.3 \mathrm{~g}$ at $100 \mathrm{mM}, 150 \mathrm{mM}$, $200 \mathrm{mM}$ and $250 \mathrm{mM}$ concentrations respectively. This showed that the effect of salt stress became more pronounced at higher salt levels of $\mathrm{NaCl}$ (Table 4). Maximum weight has been recorded at control (1.2 g) and minimum at $250 \mathrm{mM}$ in $\mathrm{KCl}(0.2 \mathrm{~g})$ and combined salts $(0.1 \mathrm{~g})$. In both $\mathrm{KCl}$ and combined salts treatments, the weight of grains was highly reduced as compared to $\mathrm{NaCl}$ stress. The effect of $\mathrm{KCl}$ and combined salts on the weight of grains were much profound as compared to $\mathrm{NaCl}$ stress (Table $4)$.

Table 1. Effect of $\mathrm{NaCl}, \mathrm{KCl}$ and combined salt stress on stem length and stem breadth (cm)

\begin{tabular}{|c|c|c|c|c|c|c|c|c|c|c|}
\hline Parameter & Treatments & \multicolumn{3}{|c|}{$\mathrm{NaCl}$} & \multicolumn{2}{|c|}{ KCL } & \multicolumn{4}{|c|}{ Combined salts } \\
\hline \multirow{6}{*}{$\begin{array}{l}\text { Stem } \\
\text { length } \\
(\mathrm{cm})\end{array}$} & & $* \mathrm{D} 1$ & $* * \mathrm{D} 2$ & $* * * \mathrm{D} 3$ & D 1 & D2 & D 3 & D 1 & D2 & D 3 \\
\hline & $100 \mathrm{mM}$ & 6.1 & 10.3 & 56.6 & 5.8 & 9.6 & 48 & 5.1 & 8.6 & 46.1 \\
\hline & $150 \mathrm{mM}$ & 5.8 & 9.7 & 52 & 5.2 & 8.9 & 45 & 4.7 & 7.5 & 40.4 \\
\hline & $200 \mathrm{mM}$ & 5.2 & 8.2 & 43.5 & 4.3 & 7.8 & 40 & 4.1 & 6.9 & 36 \\
\hline & $250 \mathrm{mM}$ & 4.2 & 7.4 & 38 & 4 & 7.2 & 36.8 & 3.6 & 6.6 & 32.2 \\
\hline & Control & 6.8 & 12.2 & 62.7 & 6.8 & 12 & 63.3 & 6.8 & 12.2 & 62.9 \\
\hline \multirow{5}{*}{$\begin{array}{c}\text { stem } \\
\text { breadth } \\
(\mathrm{cm})\end{array}$} & $100 \mathrm{mM}$ & 0.2 & 0.3 & 0.3 & 0.2 & 0.3 & 0.3 & 0.1 & 0.2 & 0.2 \\
\hline & $150 \mathrm{mM}$ & 0.2 & 0.2 & 0.3 & 0.1 & 0.2 & 0.3 & 0.1 & 0.2 & 0.2 \\
\hline & $200 \mathrm{mM}$ & 0.2 & 0.2 & 0.3 & 0.1 & 0.2 & 0.2 & 0.1 & 0.2 & 0.2 \\
\hline & $250 \mathrm{mM}$ & 0.1 & 0.2 & 0.2 & 0.1 & 0.2 & 0.2 & 0.1 & 0.2 & 0.2 \\
\hline & Control & 0.2 & 0.3 & 0.4 & 0.2 & 0.3 & 0.4 & 0.2 & 0.3 & 0.4 \\
\hline
\end{tabular}

*D1= Dose 1 (After 7 days), **D2= Dose 2 (After 14 days), ***D3= Dose 3(After 45 days) 
Table 2. Effect of $\mathrm{NaCl}, \mathrm{KCl}$ and combined salt stress on leaf length $(\mathrm{cm})$ and a number of leaves (mean)

\begin{tabular}{|c|c|c|c|c|c|c|c|c|c|c|}
\hline Parameter & Treatments & \multicolumn{4}{|c|}{ NaCl } & \multicolumn{3}{|c|}{ KCL } & \multicolumn{3}{c|}{ Combined salts } \\
\hline \multirow{4}{*}{$\begin{array}{c}\text { leaf length } \\
(\mathbf{c m})\end{array}$} & & $* \mathrm{D} 1$ & $* * \mathrm{D} 2$ & $* * * \mathrm{D} 3$ & $\mathrm{D} 1$ & $\mathrm{D} 2$ & $\mathrm{D} 3$ & $\mathrm{D} 1$ & $\mathrm{D} 2$ & $\mathrm{D} 3$ \\
\cline { 2 - 11 } & $100 \mathrm{mM}$ & 7.9 & 10.9 & 21.6 & 10 & 19 & 7.3 & 7.2 & 8.8 & 18 \\
\cline { 2 - 11 } & $150 \mathrm{mM}$ & 7.6 & 9.2 & 18.9 & 7.9 & 16 & 7 & 6.8 & 7.5 & 15 \\
\cline { 2 - 11 } & $200 \mathrm{mM}$ & 7.3 & 8.2 & 17 & 6.8 & 15 & 6.2 & 6 & 7 & 13 \\
\cline { 2 - 11 } & $250 \mathrm{mM}$ & 6.9 & 7 & 14 & 6.4 & 13 & 6 & 5.8 & 6.5 & 12 \\
\cline { 2 - 11 } & $\mathbf{C o n t r o l}$ & $\mathbf{8 . 2}$ & $\mathbf{1 2 . 9}$ & $\mathbf{2 4 . 9}$ & $\mathbf{1 2 . 9}$ & $\mathbf{2 4}$ & $\mathbf{8 . 3}$ & $\mathbf{8 . 3}$ & $\mathbf{1 2 . 9}$ & $\mathbf{2 4}$ \\
\hline \multirow{4}{*}{$\begin{array}{c}\text { number of } \\
\text { leaves }\end{array}$} & $100 \mathrm{mM}$ & 5.1 & 9.7 & 16 & 5 & 8.6 & 12 & 5 & 7.4 & 9.9 \\
\cline { 2 - 11 } & $150 \mathrm{mM}$ & 5 & 9.6 & 13 & 5 & 8 & 10 & 5 & 7 & 7.6 \\
\cline { 2 - 11 } & $200 \mathrm{mM}$ & 5 & 8.4 & 11.5 & 5 & 7.5 & 9 & 5 & 6.4 & 6.9 \\
\cline { 2 - 11 } & $250 \mathrm{mM}$ & 5 & 7.4 & 9 & 5 & 6.5 & 7 & 5 & 5.6 & 6 \\
\hline & Control & $\mathbf{0 . 2}$ & $\mathbf{0 . 3}$ & $\mathbf{0 . 4}$ & $\mathbf{5 . 1}$ & $\mathbf{9 . 7}$ & $\mathbf{1 6}$ & $\mathbf{5 . 1}$ & $\mathbf{9 . 7}$ & $\mathbf{1 5}$ \\
\hline
\end{tabular}

*D1= Dose 1 (After 7 days), **D2= Dose 2 (After 14 days), ***D3= Dose 3(After 45 days)

Table 3. Effect of $\mathrm{NaCl}, \mathrm{KCl}$ and combined salt stress on a number of tillers (mean)

\begin{tabular}{|c|c|c|c|c|c|c|c|c|c|c|}
\hline Parameter & Treatments & \multicolumn{3}{|c|}{ NaCl } & \multicolumn{3}{|c|}{ KCL } & \multicolumn{3}{c|}{ Combined salt } \\
\hline \multirow{4}{*}{$\begin{array}{c}\text { number of } \\
\text { tillers }\end{array}$} & & $* \mathrm{D} 1$ & $* * \mathrm{D} 2$ & $* * * \mathrm{D} 3$ & $\mathrm{D} 1$ & $\mathrm{D} 2$ & $\mathrm{D} 3$ & $\mathrm{D} 1$ & $\mathrm{D} 2$ & $\mathrm{D} 3$ \\
\cline { 2 - 12 } (mean) & $100 \mathrm{mM}$ & 0 & 3 & 5 & 0 & 2 & 4 & 0 & 1 & 3 \\
\cline { 2 - 11 } & $150 \mathrm{mM}$ & 0 & 2.2 & 5 & 0 & 2 & 3 & 0 & 1 & 2 \\
\cline { 2 - 11 } & $200 \mathrm{mM}$ & 0 & 2 & 4 & 0 & 1 & 2 & 0 & 1 & 1 \\
\cline { 2 - 11 } & $250 \mathrm{mM}$ & 0 & 2 & 3 & 0 & 1 & 1 & 0 & 1 & 1 \\
\cline { 2 - 10 } & Control & $\mathbf{0}$ & $\mathbf{3}$ & $\mathbf{6}$ & $\mathbf{0}$ & $\mathbf{3}$ & $\mathbf{6}$ & $\mathbf{0}$ & $\mathbf{3}$ & $\mathbf{6}$ \\
\hline
\end{tabular}

*D1= Dose 1 (After 7 days), **D2= Dose 2 (After 14 days), ***D3= Dose 3(After 45 days)

Table 4. Effect of $\mathrm{NaCl}, \mathrm{KCl}$ and combined ( $\mathrm{NaCl}, \mathrm{KCl}$ ) salt stress on spike length (cm), plant weight (g) and weight (g) of 50 grains of foxtail millet (Setaria italica)

\begin{tabular}{|c|c|c|c|c|c|c|c|c|c|}
\hline Treatments & \multicolumn{3}{|c|}{ spike length (cm) } & \multicolumn{3}{c|}{ plant weight (g) } & \multicolumn{3}{c|}{ weight (g) of 50 grains } \\
\hline & $\mathrm{NaCl}$ & $\mathrm{KCl}$ & $\begin{array}{c}\text { Combined } \\
\text { salt }\end{array}$ & $\mathrm{NaCl}$ & $\mathrm{KCl}$ & $\begin{array}{c}\text { Combined } \\
\text { salt }\end{array}$ & $\mathrm{NaCl}$ & $\mathrm{KCl}$ & Combined salt \\
\hline $\mathbf{1 0 0} \mathbf{~ m M}$ & 6.1 & 4.6 & 4.2 & 3.4 & 2.5 & 2.1 & 0.8 & 0.6 & 0.5 \\
\hline $\mathbf{1 5 0} \mathbf{~ m M}$ & 4.6 & 4.1 & 3.7 & 2.4 & 1.3 & 1.3 & 0.6 & 0.5 & 0.4 \\
\hline $\mathbf{2 0 0} \mathbf{~ m M}$ & 4 & 3.6 & 3.1 & 1.6 & 1.2 & 1.1 & 0.4 & 0.3 & 0.2 \\
\hline $\mathbf{2 5 0} \mathbf{~ m M}$ & 2.7 & 2.7 & 2.1 & 1.1 & 0.7 & 0.6 & 0.3 & 0.2 & 0.1 \\
\hline Control & $\mathbf{1 0 . 2}$ & $\mathbf{1 0 . 3}$ & $\mathbf{1 0 . 2}$ & $\mathbf{5 . 3}$ & $\mathbf{5 . 2}$ & $\mathbf{5 . 2}$ & $\mathbf{1 . 2}$ & $\mathbf{1 . 2}$ & $\mathbf{1 . 2}$ \\
\hline
\end{tabular}

\section{Discussion}

Salinity is the most important abiotic factor and badly affects seeds germination and radicle elongations of seedlings [24]. The present findings showed that salinity stress $(\mathrm{NaCl}, \mathrm{KCl}$ and combined) adversely affected seed germination and other growth parameters in foxtail millet including, length and breadth of stem, number of leaves and tillers, leaves length, spike length, weight of the whole plant, number of seeds per spike, weight of 50 seeds in all concentration. These adverse effects are concentration dependent as the plant is severely affected at higher concentration. Higher concentration of $\mathrm{NaCl}$ adversely affected all growth parameters i.e. 
relative shoot growth weight (RSGR), shoot and root dry weight, biochemical characters like total chlorophyll content and mineral elements i.e. $\mathrm{K}^{+}$and $\mathrm{K}^{+} / \mathrm{Na}^{+}$ratio in maize (Zea mays L.) [25]. Increasing salt concentrations dramatically affect both seedling emergence and growth of sunflower (Helianthus annuus L.) [26]. In comparison to $\mathrm{NaCl}$, the effect of $\mathrm{KCl}$ stress on stem breadth was slightly adverse. Salt stress has significantly reduced stem diameter in several other different plant species [27-29]. Similarly, the effect of combined salts is more severe as compared to the effect of $\mathrm{NaCl}$ and $\mathrm{KCL}$ alone. The effect of $\mathrm{KCl}$ and combined salts on plant weight were much profound as compared to $\mathrm{NaCl}$. Maximum plant weight was recorded at control $(5.3 \mathrm{~g})$ and minimum at $250 \mathrm{mM}$ in $\mathrm{KCl}(0.7 \mathrm{~g})$ and combined salts $(0.6 \mathrm{~g})$. Similar results in different plant species have also been found $[30,31]$. The combination of $\mathrm{NaCl}$ and $\mathrm{KCl}$ is a strong stressor for stem breadth in foxtail millet in higher salt concentrations. The combined stress of $\mathrm{NaCl}$ and $\mathrm{KCl}$ also reduced stem diameter of wheat [32]. The leaf length is severely affected in all the concentration of combined salts of $\mathrm{NaCl}$ and $\mathrm{KCl}$. Similarly reduction in different parameters including leaf length and a number of leaves in tomato plant has been observed [32]. By comparing results of stem length in case of combined salt treatment with individual treatments $\mathrm{NaCl}$ and $\mathrm{KCl}$, it is clear that stem length is badly affected in all the concentration of combined salts of $\mathrm{NaCl}$ and $\mathrm{KCl}$. Similar results have been obtained by many researchers in different plant species when grown under salt stress $[33,34]$.

\section{Conclusion}

It was concluded that salinity affects various growth parameters of the foxtail millet and the effects are more devastating at high concentrations in all salt treatments. Similarly, the effects of combined salts on the test plants were more pronounced as compared to the effects when the plants were treated with $\mathrm{NaCl}$ and $\mathrm{KCl}$ salts alone.

\section{Authors' contributions}

Conceived and designed the experiments: K Natasha \& SIU Haq, Performed the experiments: K Natasha, SIU Haq \& S Ahmad, Analyzed the data: K Natasha, Z Ullah \& Z Rahim, Contributed materials/ analysis/ tools: K Natasha, SIU Haq \& S Ahmad, Wrote the paper: SIU Haq.

\section{References}

1. Ravindran G (1991). Studies on millets: Proximate composition, mineral composition, and phytate and oxalate contents. Food Chem 39(1): 99-107.

2. Simova-Stoilova L, Demirevska K, Petrova T, Tsenov N \& Feller U (2009). Antioxidative protection and proteolytic activity intolerant and sensitive wheat (Triticum aestivum L.) varieties subjected to long-term field drought. Plant Growth Regul 58(1): 107117

3. Van-Heerden PDR, Kruger GHJ, Loveland JE, Parry MAJ \& Foyer $\mathrm{CH}$ (2003). Dark chilling imposes metabolic restrictions on photosynthesis in soybean. Plant Cell Environ 26: 323337.

4. Reynolds-Henne CE, Langenegger A, Mani J, Schenk N, Zumsteg A \& Feller U (2010). Interactions between temperature, drought and stomatal opening in legumes. Environ. Exp Bot 68: 37-43.

5. Meloni DA, Oliva MA, Martinez CA \& Cambraia J (2003). Photosynthesis and activity of superoxide dismutase peroxides and glutathione reduce in cotton under salt stress. Env Exp Bot 49: 69-76.

6. Tolra R, Pongrac P, Poschenricder C, Vogel-Mikus K, Regvar M \& J Barcelo (2006). Distinctive effects of cadmium on glucosinolate profile in $\mathrm{cd}$ 
hyperaccumulator Thlaspi praecox and non hyperaccumulator. Thlaspi Arvense Plant Soil 288: 333-341.

7. Gao Q \& Zhang L (2008). Ultraviolet-Binduced oxidative stress and antioxidant defense system responses in ascorbatedeficient vtc 1 mutants of Arabidopsis thaliana. J Plant Physiol 165: 138-148.

8. Vaidyanathan H, Sivakumar P, Chakrabarty R \& Thomas G (2003). Scavenging of reactive oxygen species in $\mathrm{NaCl}$-stressed rice (Oryza sativa L.) different response in salt-tolerant and sensitive varieties. Plant Sci 165: 14111418.

9. Veeranagamallaiah $\mathrm{G}$, Chandraobulreddy P, Jyothsnakuman G \& Sudhakar C (2007). Glutamine Synthetase expression and pyrroline-5 carboxylate reductase activity influence proline accumulation in two cultivars of foxtail millet (Setaria italica) with differential salt sensitivity. Environ Exp Bot 60: 239-244.

10. Sairam RK \& Tyagi A (2004). Physiological and molecular biology of salinity stress tolerance in deficient and cultivated genotypes of chickpea. Plant Growth Regulator 57(10).

11. Zhu JK (2002). Salt and drought stress signal transduction in plants. Annu Rev of Plant Biol 53(1): 247-273.

12. Pandey RK, Kumar D \& Jadhav KM (2011). Assessment of determinants for reducing $\mathrm{HCN}$ content in sorghum used for ruminant in Gujarat, India. Livestock Res Rural Devel 23(3).

13. Hasegawa PM, Bressen RAP, Zhu JK \& Bonhnert HJ (2000). Plant cellular and molecular responses to high salinity. Plant Mol Biol 51: 1463-499.

14. Hernandez JA, Jimenez A, Mullineaux $P$ $\&$ Sevill F (2000). Tolerance of Pea (Pisum sativum L.) to long-term salt stress is associated with induction of antioxidant defenses. Plant Cell Environ 23: 853-862.

15. Greenway H \& Munns R (1980). Mechanisms of salt tolerance in nonhalophytes. Annu Rev Plant Physiol 31: 149-190.

16. Munns R (2002). Comparative physiology of salt and water stress. Plant Cell Environ 25: 239-250.

17. Munns R \& Tester M (2008). Mechanisms of Salinity Tolerance. Annu Rev Plant Biol 59: 651-681.

18. FAO (2005). Land and plant nutrition management Service. http://www.Fao.org/ag/agl/agll/spush/to pic2.htm\#top.

19. Shannon M C, Grieve CM \& Francois LE (1994). Whole-plant response to salinity in Wilkinson RE (ed.) Plant Environ Interaction 199: 244

20. FAO (2008). FAO Land and Plant Nutrition Management Service. Available online: http://www.fao.org/ag/agl/agll/spush. (Accessed 27/4/2016).

21. FitzPatrick E A (1980). Properties of soil horizon in soil their formation classification and distribution. Longman Inc 81-119.

22. Shi D C \& Yin L J (1993). Difference between salt $(\mathrm{NaCl})$ and alkaline $\left(\mathrm{Na}_{2} \mathrm{Co}_{3}\right)$ stress on Puccinellia tenuiflora (Griseb). Scribn.et merger.plants, Acta Bot Sin (35): 144-149.

23. Wahid A \& Shabbir A (2005). Induction of heat stress tolerance in barley seedlings by pre-sowing seed treatment with glycine betaine. Plant Growth Regul 46: 133-141

24. Katembe WJ, Ungar IA \& Mitchell JP (1998). Effect of salinity on germination and seedling growth of two Atriplex species (Chenopodiaceae). Annals of Bot 82(2): 167-175.

25. Carpici EB, Celik N \& Bayram G (2010). The effects of salt stress on the 
growth, biochemical parameter and mineral element content of some maize (Zea mays L.) cultivars. African $J$ of Biotechnol 9(41): 6937-6942.

26. Turhan H \& Ayaz C (2004). Effect of salinity on seedling emergence and growth of sunflower (Helianthus Annuus L.) cultivars. Inter J of Agri and Bio 149152.

27. Elkhatib HA, Elkhatib EA, Khalaf AM \& El-Shakowy AM (2004). Yield response of salt stresses potato to potassium fertilizer: A Preliminary Mathematical model. J Plant Nutr 27: 111-122.

28. Tjera NA, Campus RJ, Sanjuan R \& Liunch C (2005). Effects of sodium chloride on growth, nutrient accumulation and nitrogen fixation of common bean Plants in symbiosis with isogenic strains. J Plants Nutr 28: 19071921.

29. Chang PT \& Randle WM (2005). Sodium Chloride timing and length of exposure affects onion growth and flavor. J Plant Nutr 28: 1755-1766.

30. Maathium FJH \& Amtmann A (1999). $\mathrm{K}^{+}$nutrition and $\mathrm{Na}^{+}$toxicity: the basis of cellular $\mathrm{K}^{+} / \mathrm{Na}^{+}$ratios. Ann Bot 84: 123 133.

31. Huang Y, Zhang G, Wu F, Chen J \& Zhou M (2006). Differences in physiological traits among salt-stressed barley genotypes. Common. Soil Sci Plant Anal 37: 557-570.

32. Adilogu S, Adilogue A \& M Ozkil (2007). Effects of different levels of $\mathrm{NaCl}$ and $\mathrm{KCl}$ on growth and some biological indexes of the wheat plant. Pak J Biol Sci 10(11): 1941-43.

33. Al-Ahmadi MJ \& Kafi M (2006). Salinity effects on germination properties of Kochia scoparia. Asian $J$ Plant Sci 5: 71-75.

34. Cuartero J \& Fernandez- Muhoz FR (1999). Tomato and salinity. Sci Hort 78: 83-125. 